\title{
Application of the multiagent approach to the research of integrated energy supply systems
}

\author{
Gleb Mayorov ${ }^{l}$, Valery Stennikov ${ }^{l}$, and Eugene Barakhtenko ${ }^{l}$ \\ ${ }^{1}$ Melentiev Energy Systems Institute of Siberian Branch of the Russian Academy of Sciences, Pipeline Systems Department of Energy \\ No. 50, 664033, Irkutsk Region, Irkutsk, Lermontov St., 130, Russia.
}

\begin{abstract}
The current technological infrastructure in the electricity, heat, cold, and gas supply, as a rule, is formed and controlled separately by local systems and tasks. The traditionally considered energy systems unite large energy sources, such as hydroelectric power station, combined heat and power plants, boiler plants, and electric and pipeline networks distributed over a large area. New trends in the energy sector necessitate a revision of the principles of construction of energy systems and the creation of integrated energy supply systems. Combining separate different types of systems of different levels into a single integrated system with many coordinated elements can contribute to the implementation of new functionality, the use of more advanced technologies in operation and the active participation of consumers with distributed generation in the energy supply process. For the study of integrated energy supply systems it is proposed to use a multiagent approach, which is one of the promising areas of research for complex systems. This approach is used in many subject areas to study systems that include many elements with complex behavior. Such systems include integrated energy supply systems. The solution of the problem on the basis of the agent approach is developed by a multitude of interrelated agents.
\end{abstract}

\section{Introduction}

The energy industry of the developed countries is currently experiencing a shift in the technological paradigm. It involves increasing the role of consumers, reducing the priority of centralized control and the search for compromise solutions. With an increase in the quantitative composition of technology (heating, air conditioning, electricity, modern audio and video equipment, information delivery systems and much more), the interconnection of individual systems increases, the amount of information exchanged increases, and the management of systems becomes more complex. To overcome these problems in developed countries, the idea of integrating and intellectualizing energy systems was proposed and the process of their implementation in the form of pilot projects has already begun [1-2]. Combining separate systems of different levels into a single integrated system with a large number of coordinated elements can ensure the implementation of new functionality, the use of more advanced technologies in operation and the active participation of consumers with distributed generation in the energy supply process. For the study of integrated energy supply systems, a multiagent approach is used, which is one of the promising areas of research for complex systems.

\section{Features of the multiagent approach to the research of integrated energy supply systems}

The multiagent approach is widely used in such areas as distributed problem solving, combined product design, business reengineering and building virtual enterprises, simulation modeling of integrated production systems, and electronic commerce [3-5]. The structure of the multiagent system is shown in fig. 1. For modeling and research of integrated energy supply systems (IES), this approach is of the greatest interest, since it allows the most accurate and detailed study of the mechanisms of interaction and coordination of elements of the IES.

At the core of the multiagent approach is the concept of a mobile software agent that is implemented and functions as an independent specialized computer program or an element of artificial intelligence. The essence of multiagent technology lies in a fundamentally new method of solving problems. In contrast to the classical method, when some well-defined (deterministic) algorithm is searched, which allows finding the best solution to a problem, the solution in multiagent technologies is automatically obtained as a result of the interaction of many independent, purposefully operating program modules (agents) [6-7].

An agent is any entity that is in a certain environment, perceives it through sensors, receiving data 
that reflects events occurring in the environment, interprets this data and acts on the environment through effectors (Fig. 2). Thus, four initial factors forming the agent are determined: environment, perception, interpretation, action [5].

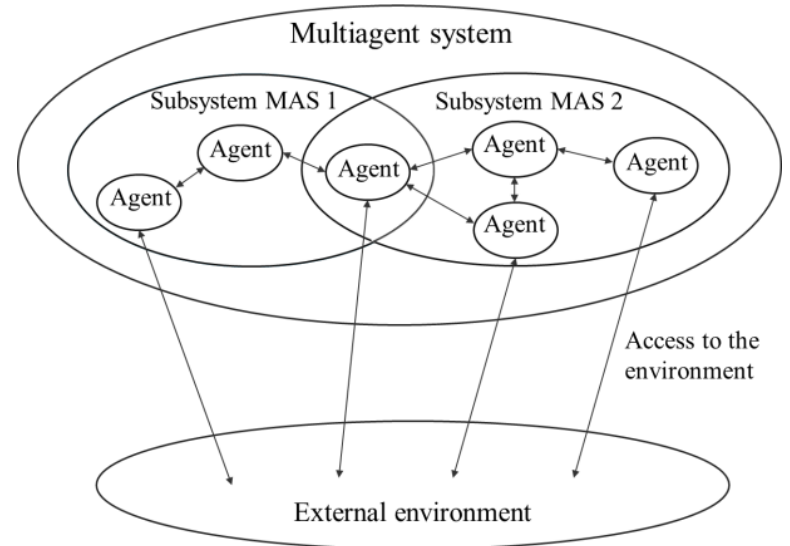

Fig. 1. Structure of multiagent system.

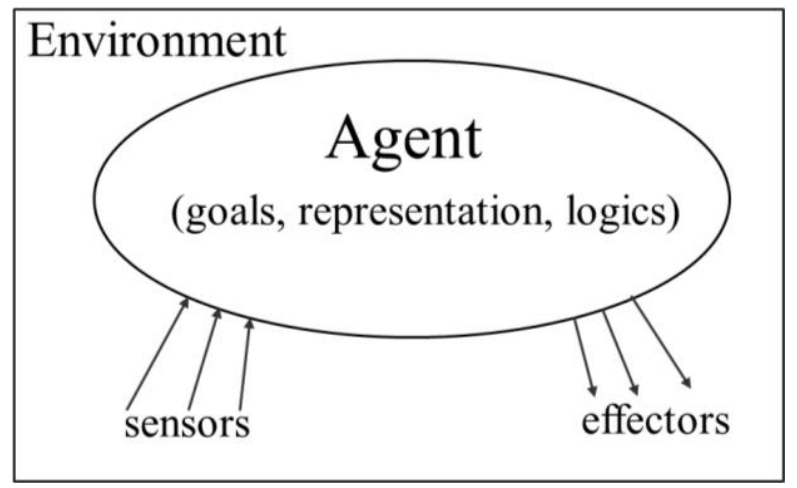

Fig. 2. Agent architecture. [7]:

Intellectual agent must have the following properties

- autonomy - the ability to function without direct intervention of people or computer means and at the same time exercise self-control over their actions and internal states;

- reactivity - the ability to perceive the state of the environment (the physical world, the user - through the user interface, sets of other agents, the Internet, or all of these components of the external environment at once);

- social behavior - the ability to interact with other agents, exchanging messages using communication languages;

- purposeful activity - the ability of agents not only to respond to the incentives coming from the environment, but also to carry out purposeful behavior, showing initiative.

\section{Integrated energy supply systems and principles of their construction using multiagent systems}

The integration of systems into a general system (metasystem) increases the level of its reliability and controllability, and the number and intensity of interconnections and interaction between individual elements increase. The main objectives of technological integration and intellectualization of energy systems are: achieving a high level of comfort in residential, public and industrial buildings; ensuring manageability, reliability, safety and efficiency; reducing the negative impact on the environment. The integration of the systems of electricity, heat (cold), gas supply is carried out at the level of production (sources of energy generation), transport (electric, heat, gas and other networks) and consumption (Fig. 3) [8-9].

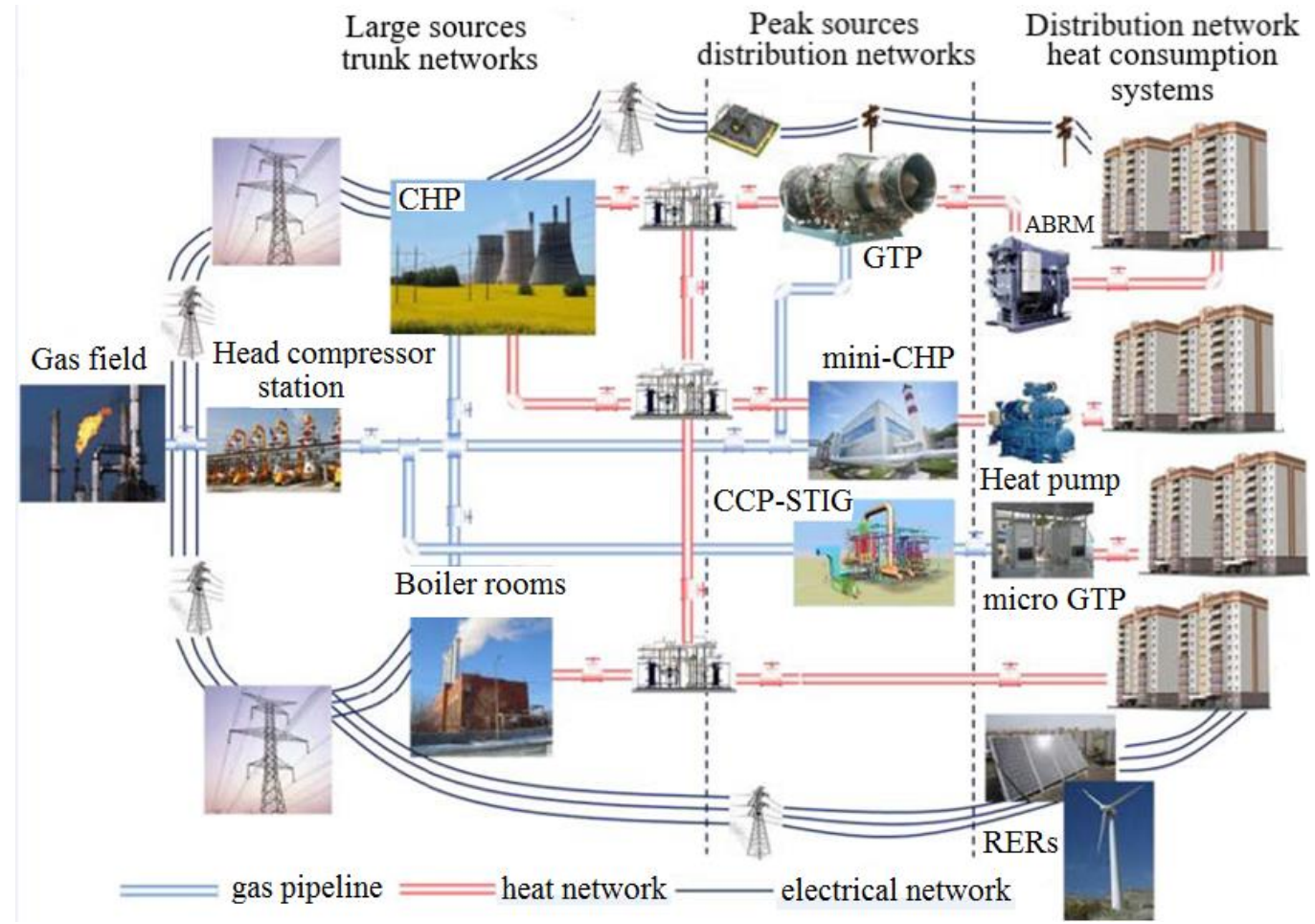

Fig. 3. Intelligent integrated energy supply system 
The creation and control of IES have already developed abroad. European countries: Germany, Denmark, the Netherlands, Finland, France, Sweden [1011], as well as China [12] have defined polygons in the form of separate cities where the IES pilot projects are being implemented $[10 ; 13]$. The most ambitious is the pilot project "United Effective Large-Scale Integrated Urban Systems" to create intelligent systems for electricity, heat (cold) supply, which is implemented in five major European cities: Gothenburg, Geneva, Cologne, London, Rotterdam [14].

The basic principles of the creation of IES $[1-2 ; 15]$ :

- Transition from the functioning of several separate systems to a common metasystem with a single control.

- Emergence, expressed in the acquisition of new properties by the metasystem, not inherent in its elements.

- Reservation systems in the process of their operation.

- Transition from a vertically subordinate control to a multiagent control (from vertical to horizontal), when each system, its element, has its own agent, who takes influence from the external environment and reacts to this influence. Decisions are made and implemented by independent centers.

- Integration of management of IES modes through network (distributed) monitoring coordination.

In fig. 4 shows the traditional hierarchical scheme for constructing an energy system and the scheme for constructing an intelligent IES.

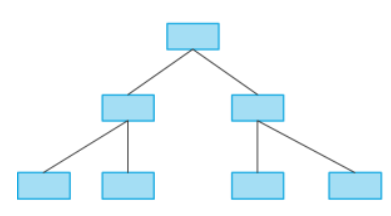

a)

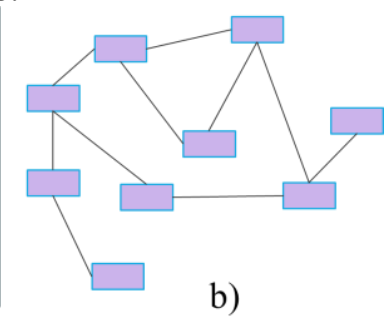

b)
Fig. 4. Schemes for the construction of energy systems: a) traditional hierarchical scheme of building an energy system; b) scheme of building an intelligent integrated energy system.
Multiagent approach for the study of the IES involves solving the following groups of tasks:

- creation of systems for collecting technological information, which are designed to accumulate the necessary data on the IES and to form a solution for managing the operation and development of the system based on the information received;

- creating a structured information technology environment, i.e. creation of a unified information environment for the IES, in which each element has its own tasks, functions, restrictions and links with other elements;

- development of software for fast data processing in the IES, so that on the basis of the information received, the system could work out the most optimal solution;

- implementation of an adaptive IES for the implementation of rapid technological control of this system, i.e. it have to be flexibility and maneuverability, respond quickly to complex and emergency situations.

The structure of the developed multiagent system (MAS) reflects the features of the scheme for constructing an intelligent IES. It is divided into appropriate levels and includes vertical and horizontal connections between the elements of the system, in contrast to the traditional hierarchical scheme, where the interaction takes place vertically, strictly from the bottom up. But at the same time, in the developed MAS there is a general coordinating body that contains information about the entire system and monitors the system parameters so that they do not go beyond the specified limits.

\section{Multilevel structure of multiagent systems to the research of integrated energy supply systems}

The considered MAS for the study of IES is divided into three levels: the metalevel, the level of systems, the level of subsystems (Fig. 5).

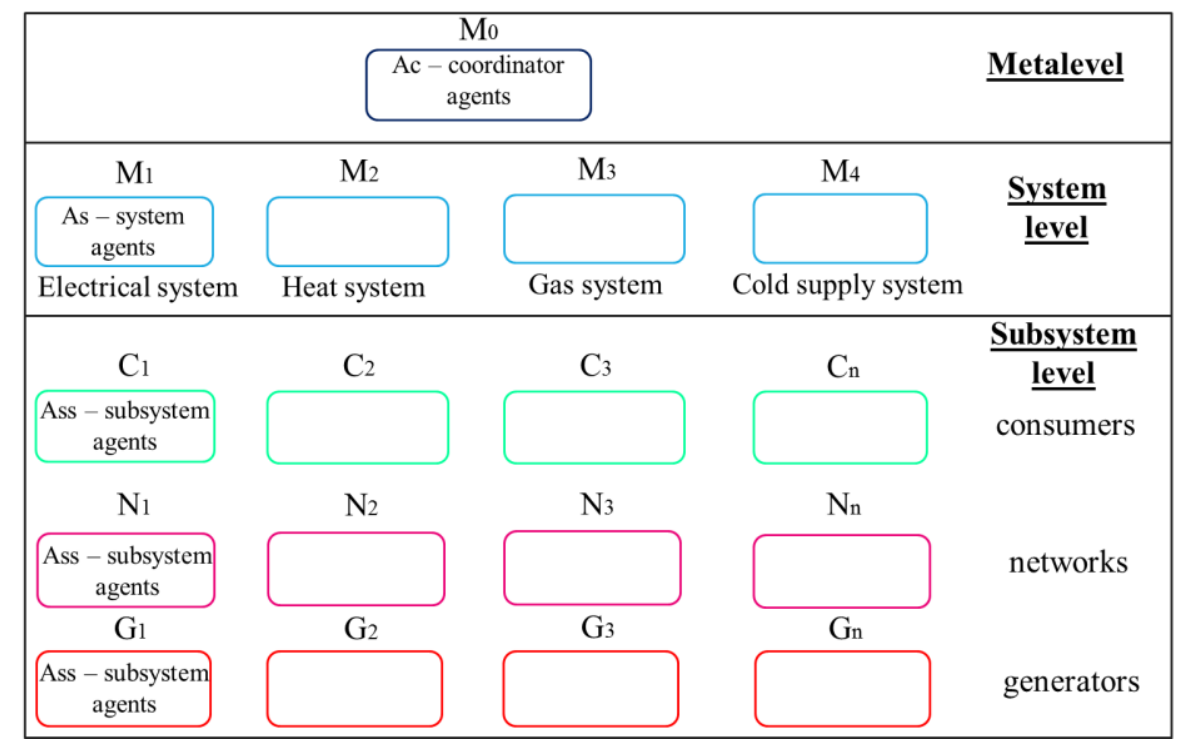

Fig. 5. The structure of the integrated energy supply system. 


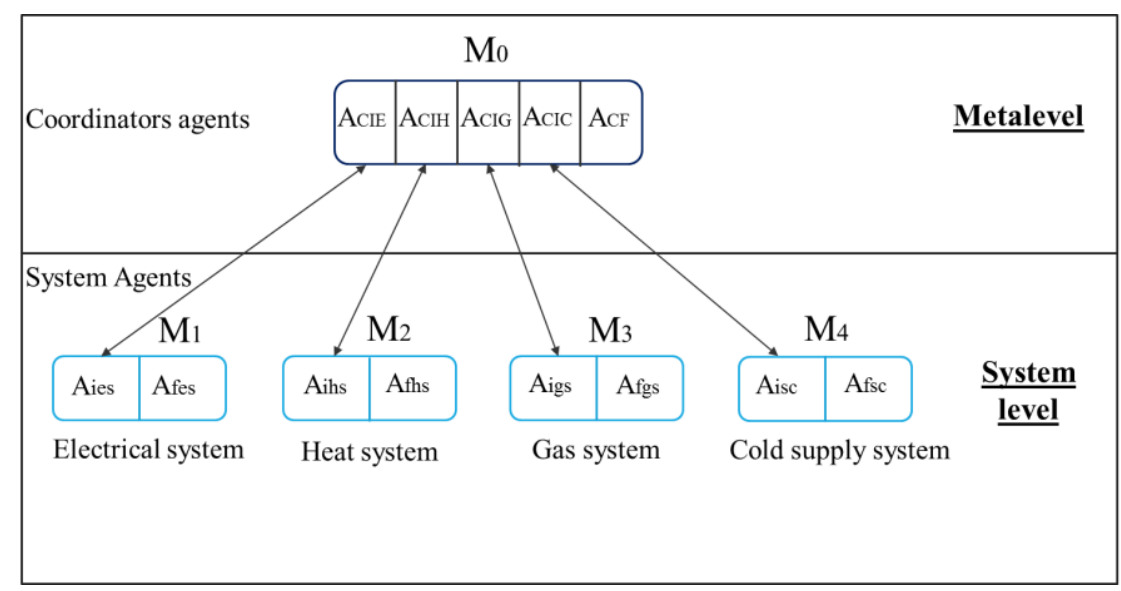

Fig. 6. Interaction of agents of the metalevel with agents of systems.

Coordinator agents of the metalevel, who generally monitor the entire system and in critical situations when the system cannot cope with them, manage (Fig. 6). These agents have certain restrictions and operate within the regulatory parameters set by the system (Table 1). Coordinator agents are divided into information agents and control agents. Information agents differentiated by type: ACIE - the information coordinator agent of the electrical system; ACIT - the information coordinator agent of the thermal system; ACIG - the information coordinator agent of the gas system; ACIC - the information coordinator agent of the cold supply system. The presented agents of the metalevel exchange data with the information agents of the systems (electrical, thermal, gas, and cold supply), and control the solutions obtained for the functioning problems developed as a result of the interaction of the agents of the systems. If necessary, they adjust the resulting solutions to ensure the specified constraints. In critical situations, when it is impossible to independently develop a solution at the system level, the information coordinator agents develop a solution and transfer it to the control coordinator agent, it forms control actions and implements it.

Table 1. Metalevel agents, their goals and tasks.

\begin{tabular}{|c|c|c|}
\hline Agents & Goals and tasks & Restrictions \\
\hline 1 & 2 & 3 \\
\hline $\begin{array}{l}\text { 1. Control } \\
\text { coordinator } \\
\text { agent }\end{array}$ & $\begin{array}{l}\text { In emergency or } \\
\text { severe situations, } \\
\text { after receiving } \\
\text { relevant information } \\
\text { from information } \\
\text { agents, it produces } \\
\text { control actions. }\end{array}$ & $\begin{array}{l}\text { Capabilities of } \\
\text { generating } \\
\text { equipment, } \\
\text { network } \\
\text { bandwidth, safety } \\
\text { requirements } \\
\text { ntinuation of table 1 }\end{array}$ \\
\hline $\begin{array}{l}\text { 2. Information } \\
\text { coordinator } \\
\text { agent of the } \\
\text { electrical } \\
\text { system }\end{array}$ & $\begin{array}{l}\text { In general, monitors } \\
\text { the electrical } \\
\text { system, exchanges } \\
\text { information with the } \\
\text { agents of the } \\
\text { electrical system and } \\
\text { other coordinators } \\
\text { agents in an } \\
\text { emergency or } \\
\text { complex situation } \\
\text { can form a solution }\end{array}$ & $\begin{array}{c}\text { Possibilities of } \\
\text { informational } \\
\text { communication } \\
\text { channels, } \\
\text { availability of } \\
\text { communication } \\
\text { channels with other } \\
\text { agents }\end{array}$ \\
\hline
\end{tabular}

\begin{tabular}{|c|c|c|}
\hline $\begin{array}{l}\text { 3. Information } \\
\text { coordinator } \\
\text { agent of the } \\
\text { thermal system }\end{array}$ & $\begin{array}{l}\text { In general, he } \\
\text { monitors the heat } \\
\text { system, exchanges } \\
\text { information with the } \\
\text { agents of the heat } \\
\text { system and other } \\
\text { coordinators agents, } \\
\text { in an emergency or } \\
\text { complex situation } \\
\text { may form a solution } \\
\text { to the problem }\end{array}$ & $\begin{array}{c}\text { Possibilities of } \\
\text { informational } \\
\text { communication } \\
\text { channels, } \\
\text { availability of } \\
\text { communication } \\
\text { channels with other } \\
\text { agents }\end{array}$ \\
\hline $\begin{array}{l}\text { 4. Information } \\
\text { coordinator } \\
\text { agent of the } \\
\text { gas system }\end{array}$ & $\begin{array}{l}\text { In general, he } \\
\text { monitors the gas } \\
\text { system, exchanges } \\
\text { information with } \\
\text { agents of the gas } \\
\text { system and other } \\
\text { coordinators agents, } \\
\text { in an emergency or } \\
\text { complex situation } \\
\text { may form a solution } \\
\text { to the problem }\end{array}$ & $\begin{array}{c}\text { Possibilities of } \\
\text { informational } \\
\text { communication } \\
\text { channels, } \\
\text { availability of } \\
\text { communication } \\
\text { channels with other } \\
\text { agents }\end{array}$ \\
\hline $\begin{array}{l}\text { 5. Information } \\
\text { coordinator } \\
\text { agent system } \\
\text { for cold supply }\end{array}$ & $\begin{array}{l}\text { In general, it } \\
\text { monitors the cold } \\
\text { supply system, } \\
\text { exchanges } \\
\text { information with } \\
\text { agents of the cold } \\
\text { supply system and } \\
\text { other coordinating } \\
\text { agents, in an } \\
\text { emergency or } \\
\text { difficult situation it } \\
\text { can form a solution } \\
\text { to the problem }\end{array}$ & $\begin{array}{l}\text { Possibilities of } \\
\text { informational } \\
\text { communication } \\
\text { channels, } \\
\text { availability of } \\
\text { communication } \\
\text { channels with other } \\
\text { agents }\end{array}$ \\
\hline
\end{tabular}

At the next level, the IES decomposes into four main systems according to a technological basis: electrical, heat, gas, cold supply. Each system has two types of agents: informational and control (Table 2). Information agents exchange information with metalevel agents, agents of other systems and agents of subsystems (Fig. 7). Control agents in difficult situations after receiving data from information agents can make the necessary switch. 


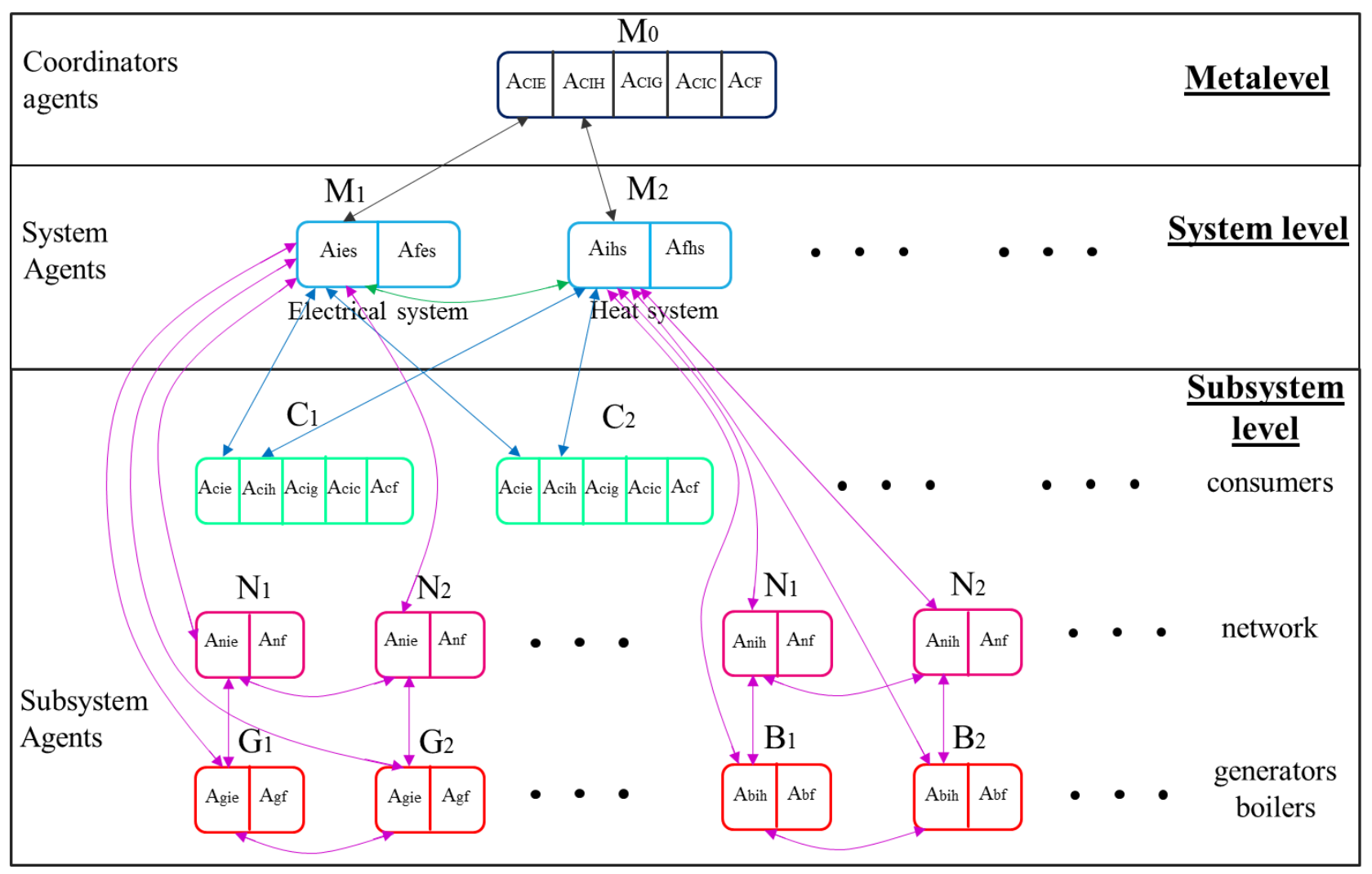

Fig. 7. Interaction of system agents with metalevel agents and subsystem agents.

Table 2. System agents, their goals and tasks.

\begin{tabular}{|c|c|c|}
\hline Agents & Goals and tasks & Restrictions \\
\hline 1 & 2 & 3 \\
\hline $\begin{array}{l}\text { 1. Information } \\
\text { agent of the } \\
\text { electrical system }\end{array}$ & $\begin{array}{l}\text { Receives applications for the required amount of electricity with the } \\
\text { specified parameters from the consumer's agents and distributes them } \\
\text { between the network and generation agents, exchanges information } \\
\text { about the system with agents of other systems, coordinating agents, if } \\
\text { necessary, can generate a solution to the problem }\end{array}$ & $\begin{array}{l}\text { Possibilities of informational } \\
\text { communication channels, } \\
\text { availability of communication } \\
\text { channels with other agents }\end{array}$ \\
\hline $\begin{array}{c}\text { 2. Control agent } \\
\text { of the electrical } \\
\text { system } \\
\end{array}$ & $\begin{array}{l}\text { In emergency or severe situations, after receiving relevant information } \\
\text { from information agents, it produces control actions. }\end{array}$ & $\begin{array}{c}\text { Capabilities of generating } \\
\text { equipment, network bandwidth, } \\
\text { safety requirements }\end{array}$ \\
\hline $\begin{array}{l}\text { 3. Information } \\
\text { agent of the } \\
\text { thermal system }\end{array}$ & $\begin{array}{l}\text { Receives applications for the required amount of heat with specified } \\
\text { parameters from consumer agents and distributes them between } \\
\text { network and generation agents, exchanges information about the } \\
\text { system with agents of other systems, coordinating agents, if necessary, } \\
\text { can generate a solution to the problem }\end{array}$ & $\begin{array}{l}\text { Possibilities of informational } \\
\text { communication channels, } \\
\text { availability of communication } \\
\text { channels with other agents }\end{array}$ \\
\hline $\begin{array}{l}\text { 4. Control agent } \\
\text { of the thermal } \\
\text { system }\end{array}$ & $\begin{array}{l}\text { In emergency or severe situations, after receiving relevant information } \\
\text { from information agents, it produces control actions. }\end{array}$ & $\begin{array}{c}\text { Capabilities of generating } \\
\text { equipment, network bandwidth, } \\
\text { safety requirements }\end{array}$ \\
\hline $\begin{array}{l}\text { 5. Information } \\
\text { agent of the gas } \\
\text { system }\end{array}$ & $\begin{array}{l}\text { Receives applications for the required amount of gas with specified } \\
\text { parameters from consumer agents and distributes them between } \\
\text { network and generation agents, exchanges information about the } \\
\text { system with agents of other systems, coordinating agents, if necessary, } \\
\text { can generate a solution to the problem }\end{array}$ & $\begin{array}{l}\text { Possibilities of informational } \\
\text { communication channels, } \\
\text { availability of communication } \\
\text { channels with other agents }\end{array}$ \\
\hline $\begin{array}{l}\text { 6. Control agent } \\
\text { of the gas system }\end{array}$ & $\begin{array}{l}\text { In emergency or severe situations, after receiving relevant information } \\
\text { from information agents, it produces control actions. }\end{array}$ & $\begin{array}{c}\text { Capabilities of generating } \\
\text { equipment, network bandwidth, } \\
\text { safety requirements }\end{array}$ \\
\hline $\begin{array}{l}\text { 7. Information } \\
\text { agent system for } \\
\text { cold supply }\end{array}$ & $\begin{array}{c}\text { Receives applications for the required amount of cold energy with } \\
\text { specified parameters from consumer agents and distributes them } \\
\text { between network and generation agents, exchanges system information } \\
\text { with agents of other systems, coordinating agents, and if necessary, can } \\
\text { form a solution to the problem }\end{array}$ & $\begin{array}{l}\text { Possibilities of informational } \\
\text { communication channels, } \\
\text { availability of communication } \\
\text { channels with other agents }\end{array}$ \\
\hline $\begin{array}{l}\text { 8. Control agent } \\
\text { system for cold } \\
\text { supply }\end{array}$ & $\begin{array}{l}\text { In emergency or severe situations, after receiving relevant information } \\
\text { from information agents, it produces control actions. }\end{array}$ & $\begin{array}{l}\text { Capabilities of generating } \\
\text { equipment, network bandwidth, } \\
\text { safety requirements }\end{array}$ \\
\hline
\end{tabular}


At the subsystem level, there is a functional division of objects into: consumers, networks, generation. The consumer also has two types of information and control agents. Information agents are divided into four types: Acie - agent for electricity; Acih - heat agent; Acig - gas supply agent; Acic - cold supply agent. Network and generation objects have two agents for one information and control.

Information agents systems accept requests from consumer agents and distribute them between the network and generation agents. Then the network and generation agents at their level interact with each other and develop a common solution. Each subsystem has its own restrictions, for example, restrictions on the generated power or on the network bandwidth. If a common solution cannot be found at the subsystem level, then the agents of the subsystems inform the system agents about this, and those at their level try to solve the set task. Based on the interaction between the energy supply systems, it is possible to redistribute and convert energy from different sources, for example, if there is not enough electric energy, it is possible to get the required amount of energy through specially used standby generators (working on gas or using steam energy).

\section{Results}

This article discusses the problem of creating IES, proposed principles for their construction. The analysis of the possibility of using multiagent approach to their control. The structure of the MAS for the study of the IES is presented, within which the main agents of the MAS, their goals and objectives are identified.

The theoretical significance of the proposed development lies in the justification of the methods and principles for modeling integrated energy supply systems based on multiagent technologies.

The practical significance of the research is determined by the development of software prototype of the MAS for the study of integrated energy supply systems, and the ability to simulate real energy supply systems based on this prototype.

The research was carried out under State Assignment, Project 17.4.1 (reg. no. AAAA-A17117030310432-9) of the Fundamental Research of Siberian Branch of the Russian Academy of Sciences.

\section{References}

1. Voropai N.I., Stennikov V.A., Barakhtenko E.A. Methodological principles of constructing the integrated energy supply systems and their technological architecture. Journal of Physics: Conference Series, vol. 1111, no. 1, pages 012001, (2018)

2. Voropai N.I., Stennikov V.A., Senderov S.M., Barakhtenko E.A. et al. Integrated infrastructural energy systems of regional and interregional level. Energy policy, no.3, pp. 24-32, (2015)
3. Gorodetskii V.I. Multi-agent systems: basic properties and behavior coordination models. Information technology and computing systems, no. 1, pp. 22-34, (1998)

4. Gorodetskii V.I., Karsaev O.V., Samoilov V.V., Serebriakov S.V. Applied multi-agent group management systems. Artificial Intelligence and Decision Making, no. 2, pp. 3-24, (2009)

5. Rassel S., Norvig P. Artificial intelligence: a modern approach. 2_e ed. Williams Publishing, 1408 p, (2006)

6. Tarasov V.B. Agents, multiagent systems, virtual communities: a strategic direction in computer science and artificial intelligence. Artificial intelligence news, no. 2, pp. 5-63, (1998)

7. Wooldridge M., Jennings N. Intelligent Agents: Theory and Practice. The Knowledge Engineering Review, Vol.10, no. 2. pp. 115-152, (1995)

8. Voropai N.I., Beliaev L.S., Lagerev A.V., Posekalin V.V. et al. Energy of the 21 st Century: Development conditions, technologies, forecasts. Novosibirsk, Science, 386 p. (2004)

9. Voropai N.I., Podkoval'nikov S.V., Senderov S.M., Stennikov V.A. et al. Energy of the 21st Century: Energy Systems and Their Management. Novosibirsk, Science, 364 p. (2004)

10. Linking Heat and Electricity Systems. Co-generation and District Heating and Cooling Solutions for a Clean Energy Future. IEA Publishing, Paris, 62 p. (2014)

11. René Verhoeven, Eric Willems, Virginie HarcouëtMenou, Eva De Boever, Louis Hiddes, Peter Op't Veld, Elianne Demollin. Minewater 2.0 Project in Heerlen the Netherlands: Transformation of a Geothermal Mine Water Pilot Project into a Full Scale Hybrid Sustainable Energy Infrastructure for Heating and Cooling. Energy Procedia 46, pp. 58-67, (2014)

12. Ran X., Zhou R., Yang Y., Lin L. The MultiObjective Optimization Dispatch of Combined Cold Heat and Power Based on the Principle of Equal Emission. 2012 IEEE Power and Energy Society General Meeting. San Diego, United States, 22-26 July, Pp. 1-5, (2012). doi: 10.1109/PESGM.2012.6345053.

13. Celsius Consortium. [Electronic resource]. Access mode: http://celsiuscity.eu/demonstrator/.

14. [Electronic resource]. Access mode: http://eusmartcities.eu.

15. Voropai N.I., Stennikov V.A. Integrated Intelligent Energy Systems. Proceedings of the Academy of Sciences. Energy, no. 1, pp. 64-73, (2014) 